
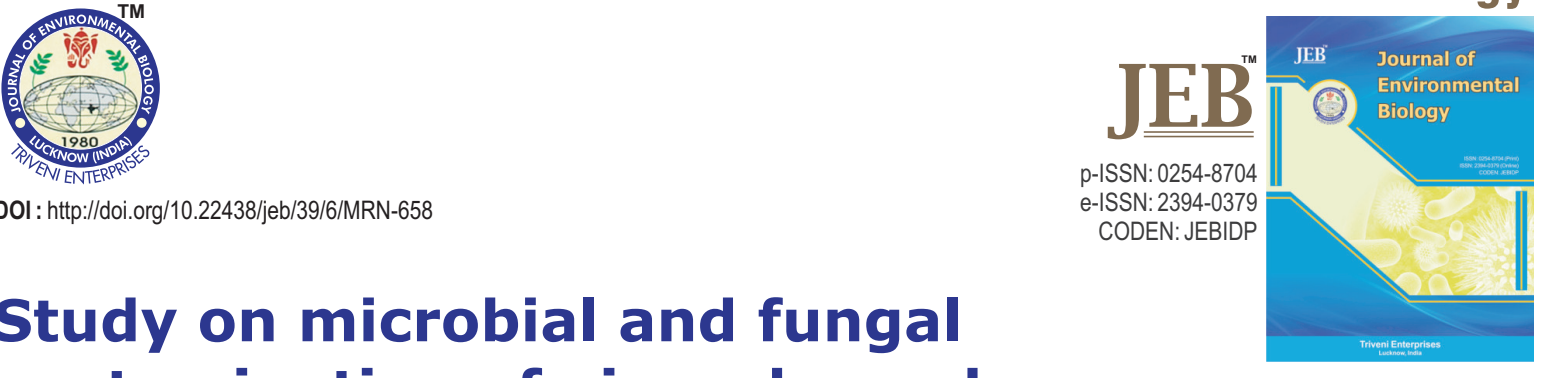

\title{
Study on microbial and fungal contamination of air and wooden surfaces inside of a historical Church from Romania
}

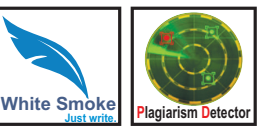

\section{Authors Info}

D.C. Ilieș ${ }^{1}$, A. Onet ${ }^{2 *}$, J.A. Wendt', M. Ilieș ${ }^{4}$ A. Timar', A. Ilieș', Ș. Baias and G.V. Herman

${ }^{1}$ Faculty of Geography, Tourism and Sport, University of Oradea, Oradea, 410087, Romania

${ }^{2}$ Faculty of Environmental Protection, University of Oradea, Oradea, 410048, Romania

${ }^{3}$ Faculty of Oceanography and Geography, University of Gdańsk, Gdańsk, 80-309, Poland

${ }^{4}$ Faculty of Geography, University "Babes Bolyai" Cluj Napoca, Extension Sighetu Marmatiei, 435500, Romania

${ }^{*}$ Corresponding Author Email : aurelia_onet@yahoo.com

Key words

Airborne transmission

Bio-deterioration

Microaeroflora

Wooden church

\section{Publication Info}

Paper received : 25.05.2017

Revised received : 23.10.2017

Re-revised received : 20.01.2018

Accepted: 06.02.2018

\begin{abstract}
Aim : The degree of microbial contamination of air and surfaces reflect a potential risk of disease which increases proportionally with the density of microorganisms and the presence of pathogenic or potentially pathogenic species. The paper focus on the degree of bacterial and fungal contamination of air and surfaces inside a historical wooden church from Oradea city, Romania.
\end{abstract}

Methodology : The conventional technique of open plates (Koch sedimentation method) was used for the microaeroflora inside the wooden church. The air samples were taken from two places (from the middle of the room and from a corner, both places being at the same height), during different times of the day. In order to determine the fungi types present on the wood surfaces, dust samples were collected from five places inside the wooden church.

Results : The results obtained showed that the bacterial contamination of air had reached the maximum limit of $100 \mathrm{CFU} / 4 \mathrm{hrs}$, meanwhile fungal contamination had exceeded the contamination level $\mathrm{C}$ which provides $50 \mathrm{CFU} / 4$ hrs according to the European Union Guide to Good Manufacturing Practice (1997). The fungi identified in the air inside of the wooden church belong to the genus : Aspergillus, Penicillium, Stachybotrys, Scopulariopsis, Arthrinium, Mucor, Rhizopus, Absidia and Geotrichum.

Interpretation: The results obtained from the analysis of microaeroflora inside the wooden church highlights the presence of various species of fungi with potential health risk at worship place. The environmental conditions present within the church favours the development of fungi and bacteria.

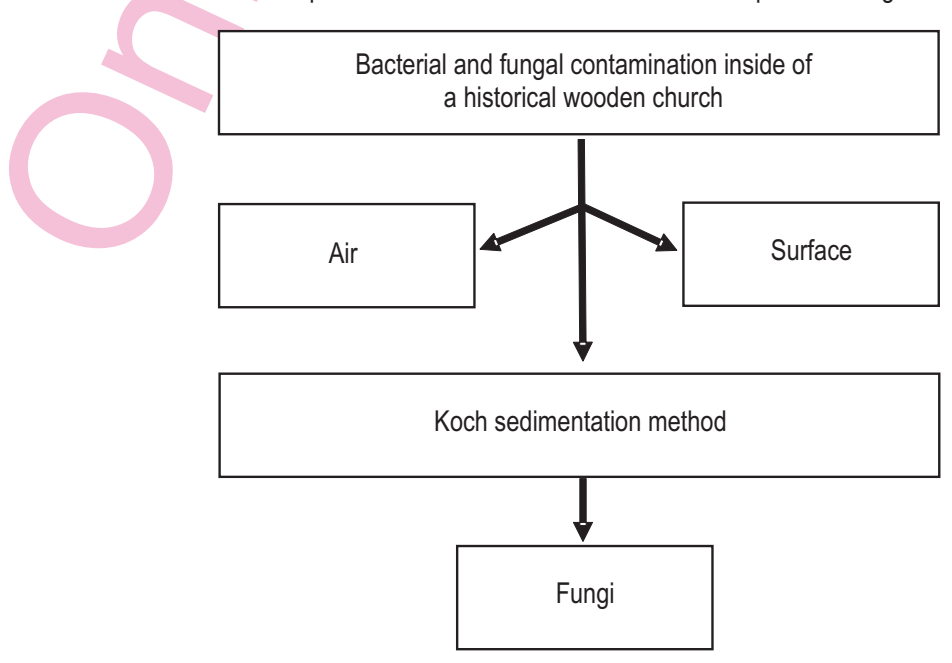




\section{Introduction}

Indoor air quality is an issue of public concern as people spend most of their time indoors (Mondal et al., 2013). Air contamination is closely related to the degree of contamination of surfaces and objects, which are frequently contaminated with microbial flora present in the air. Once the dust is rising in the air, there are many microorganisms and spores on the surfaces. The significance of the presence and number of germs on surfaces is similar to the meaning of their existence in the air, so that a high density of germs reflects both an increased epidemiological risk in the rooms and evidence of inadequate sanitary conditions (Gent et al., 2002; Dales et al., 1991). The flora from the rooms' air and generally from the enclosed spaces play an important role in the airborne transmission of infectious diseases, especially in crowded or poor ventilation conditions (Yasir et al., 2015; Howard-Reed et al., 2003). The initial geographical location of the wooden church "St. Martyrs Constantin Brancoveanu and His Sons, "St. Archangels Michael and Gabriel "was in the village Letca, Salaj County $\left(18^{\text {th }}\right.$ century), which impressed with its specific features being included in the great European family of wood churches (llieș et al., 2011; llieș, 2013; llieș et al., 2014; Ilies et al., 2016; Baias et al., 2015). In 1993, the wooden church was displaced and moved into the campus of the University of Oradea (Bihor County), located in north-western part of Romania. Since 2010, the wooden church is on the new list of historical monuments (BH-II mB- 20958 m) (Godea et al., 1978).

The deteriorations caused by fungi as well as by rainwater infiltration are the most common causes of degradation in the most historic wooden buildings (Akgul et al., 2015; Timar et al., 2009; Capatana et al., 2007). The development of fungi is influenced by a number of factors such as temperature, humidity and appearance of nutrients. In certain conditions of microclimate specific to multiplication, the fungi can contaminate almost all the surfaces. The presence of fungi in the indoor air should not be tolerated as the fungal spores, mycelial fragments and mycotoxins are the major cause of respiratory diseases and allergies (Bucsa et al., 2008; Vlad, 2009). The present study was aimed at evaluating microbial and fungal contamination of air and dust inside the mentioned historic wooden church.

\section{Materials and Methods}

Air sampling procedure : The microaeroflora was analysed by conventional techniques of open plates called Koch sedimentation method (Spengler et al., 2008). The sedimentation method consisted in exposing the Petri plates with a diameter of $90 \mathrm{~cm}$ that contain specific culture medium, at two places, inside the wooden church for four hours. In each exposing place there have been used two Petri plate groups, each group including one plate with nutrient agar medium for quantitative analysis of bacteria and the other with Sabouraud agar medium with the addition of chloramphenicol $\left(0.5 \mathrm{gl}^{-1}\right)$ for the quantitative determination of fungi. A group of plates was exposed in the middle of the room at the height of the table $(60-100 \mathrm{~cm}$ from the floor) and the second group was exposed in a corner of the room at the same height.
The exposure was carried out by opening the lids of Petri plates and their placement with opening part towards the ground altogether with the culture medium plates. After exposure, the Petri plates were coated and were transported to the laboratory. In laboratory, they were incubated in a thermostat for 5 days at $25^{\circ} \mathrm{C}$ to determine the total number of fungi expressed in CFU m ${ }^{-3}$ of air (colony forming units) and for $24 \mathrm{hrs}$ at $37^{\circ} \mathrm{C}$ for determining the total mesophilic aerobic bacteria (CFU $\mathrm{m}^{-3}$ ). After the incubation period, the colonies were counted on each plate with the same culture medium and the arithmetic mean was calculated (Azari etal., 2008).

Microorganisms present in a volume of air, a transformation of the number of germs on the surface of the plate into the number of germs per volume of air are required. Thus, the results were expressed with the help of Omelianski calculus formula based on the observation according to which on a surface of $100 \mathrm{~cm}^{2}$ exposed for a certain period of time, the number of germs equal to that contained in $10 \mathrm{dm}^{3}$ of air (Cernei et al., 2013) was deposited.

Dust sampling procedure : Samples from surfaces were taken from 5 places represented by : painted canvas located at the entrance hall of the church, interior left wall, interior right wall, alter apse and the right exterior wall under the roof. The swab was used to wipe an area of $100 \mathrm{~cm}^{2}$ delineated by the outline. Before the sampling procedure began, the swab was moistened in sterile water. Sampling was performed by passing the swab rod for three times through the same place in different directions (Rached et al., 2013). The samples were transported to the Microbiology Laboratory, Faculty of Environmental Protection, University of Oradea and were subjected to fungal culture from which viable colonies were identified (the plates were incubated for 5 days at $25^{\circ} \mathrm{C}$ ). The identification was based on the morphological characteristics of fungal colonies (shape, colour, texture, etc.) as well as microscopic examination techniques (morphological characteristics of the hyphae and conidia cells).

\section{Results and Discussion}

The total number of aerobic mesophilic bacteria and total number of fungi were determined in the air inside the wooden church by sedimentation method. Air samples were collected by passive air sampling (the settle plates) because only microorganisms that settle onto the agar surfaces are detected, settling plates can be used as qualitative or semi-quantitative air monitors (Samuel et al., 2014). Determination of total number of germs developing in the air inside the rooms at $37^{\circ} \mathrm{C}$ allows us to appreciate the air loading level with flora of human origin as well as hygiene specific conditions (overcrowding, ventilation, cleanliness, etc.) that influence the transmission of airborne infections (Gorny, 2004).

After counting the colonies with colony counter, 47 bacterial colonies and 31 fungal colonies were observed. In order to calculate the number of germs present in one $\mathrm{m}^{3}$ of air, the results obtained were interpolated in Omelianski's formula to give 
100 bacterial cells $\cdot \mathrm{m}^{-3}$ of air and 65 colony-forming units $\cdot \mathrm{m}^{-3}$ of air regarding the concentration of fungi (Fig. 1).

A quantitative interpretation of the results describing the air quality inside the wooden church is difficult. The legislative framework from Romania doesn't foresee certain threshold levels for the exposure to pollutants of the indoor ambiental air. Universally applicable standards defining an acceptable level of indoor air contamination with microorganisms have not been established yet (Samuel et al., 2014). According to the recommended limits for microbial contamination provided by the Pharmaceutical Cleanroom Classification, the results show that the bacterial contamination of air had reached the maximum limit of $100 \mathrm{CFU}$ per $4 \mathrm{hrs}$. Meanwhile, the fungal contamination had exceeded $50 \mathrm{CFU}$ per $4 \mathrm{hrs}$. The results highlight the fact that the air inside the small wooden church is a potential risk to human health. A human inhales more than $14 \mathrm{~m}^{3}$ of air daily. This leads to the theory that the airborne microbial intake per day of the parishioners might likely exceed by at least 14 -fold the average number of the microorganisms determined after the air quality monitoring inside the wooden church (Brochu et al., 2006). To prevent possible health risks of the people coming to the church,
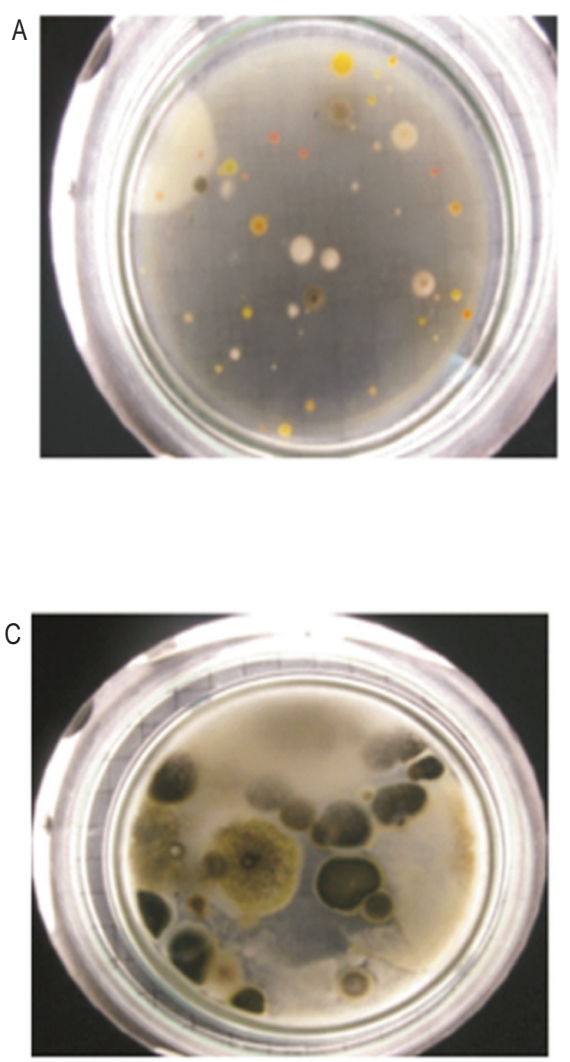

it is important to control the environmental factors which favour the growth and multiplication of the indoor microbes. Huixing (2017) tested the microorganism concentration in the constant temperature and humidity air conditioning system and the effect of microbial concentration on the cultural relics. The results reported cultural relics damage. The fungi present in the dust on the surfaces inside the historical monument wooden church may be incriminated in the biodeterioration of the church wood and in the production of respiratory and allergic diseases in the case of some species with pathogenic risk (Katja, 2010). Based on the morphological characteristics of the colonies and microscopic examination of mycelium and conidial structures, various fungi types were determined. The fungi identified from surface samples and from microaeroflora belonged to the following genus: Aspergillus, Penicillium, Stachybotrys, Scopulariopsis, Arthrinium, Mucor, Rhizopus, Absidia and Geotrichum (Fig. 2). These fungi types are recognized as opportunistic pathogens for humans and are often associated with clinical manifestations (Bush, 2006).

Penicillium and Aspergillus are the most common indoor fungi. These fungi produce a variety of toxic chemical substances
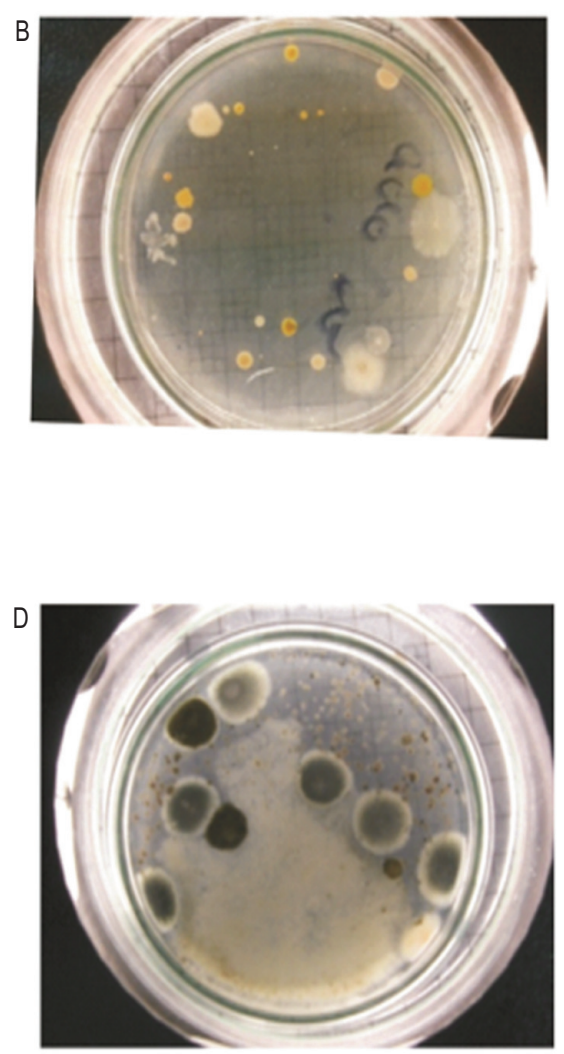

Fig. 1 : Determination of microaeroflora: A, B - Petri plates with nutrient agar culture medium for counting the aerobic mesophilic bacteria; C, D - Petri plates with agar Sabouraud culture medium for counting the fungi. 
called mycotoxins (Miller, 1992). Aspergillus is one of the most infectious fungi causing aspergillosis and is also an opportunistic pathogen (Anagnost et al., 2006). According to Occupational Safety and Health Administration, the species from Scopulariopsis genus are classified as allergens and irritants as they cause dermatitis and allergic alveolitis (Gorny et al., 2002). Fungi of Stachybotrys genus are found commonly in the air in homes and the spores can cause possible health risks (Gent et al., 2002; Brunekreef et al., 1989). The species belonging to genus Mucor and Rhyzopus are potentially pathogenic contaminants. Rhizopus is considered a major allergen responsible for allergies of occupational nature (Yassin et al., 2010). The species of the genus Absidia can produce zygomycosis and rhinocerebral infections. Trichoderma is a potentially pathogenic mold (Zehra, 2017). It can be found in indoor air because it prefers cellulose, produces mycotoxins
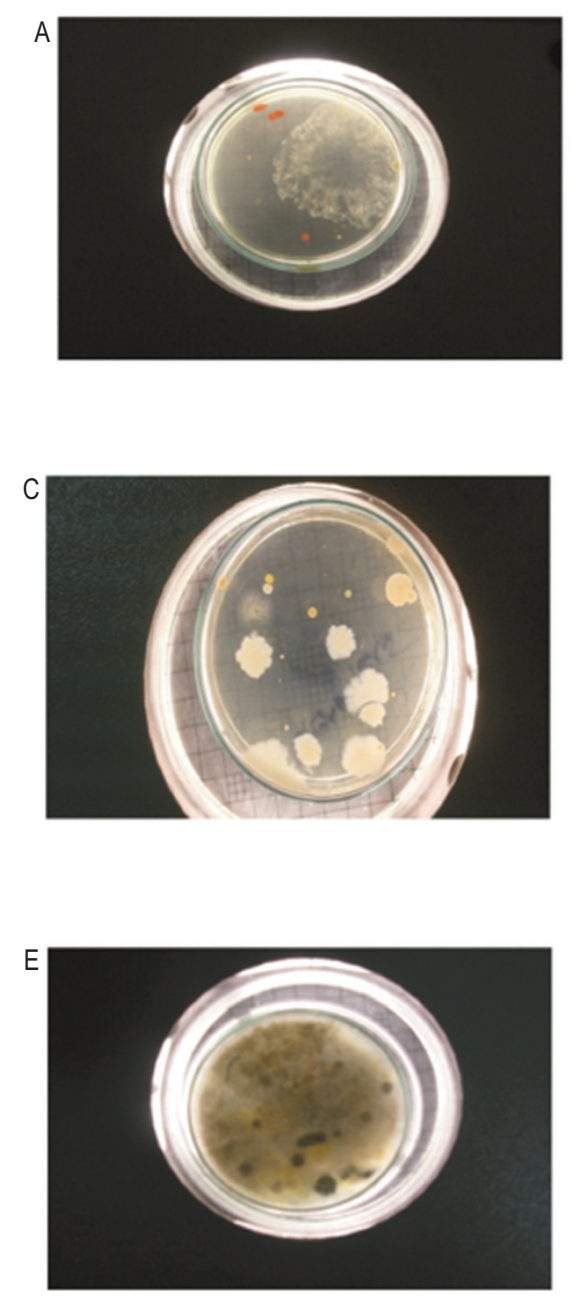

and that is why it is an important mold in the investigations regarding the indoor air quality (Stark et al., 2003). Indoor fungi spread by air may have adverse effects on human health (Onet, 2012). Exposure to indoor fungi and mycotoxins that can be absorbed by the respiratory tract, can be a major risk to human health through all the three known mechanisms : infection, allergy and toxicity (Terr, 2014). The evaluation of microbial air quality and fungal surface contamination inside the wooden church highlights the presence of various species with potential health risk on the parishioners and the people in charge of maintaining the church. The high values obtained in terms of bacterial and fungal load of the air inside the wooden church indicates that the prolonged exposure to identified fungal species is a real danger to human health considering that biodeterioration is not visible to the naked eye, but it affects the internal structure of the wood substrate.
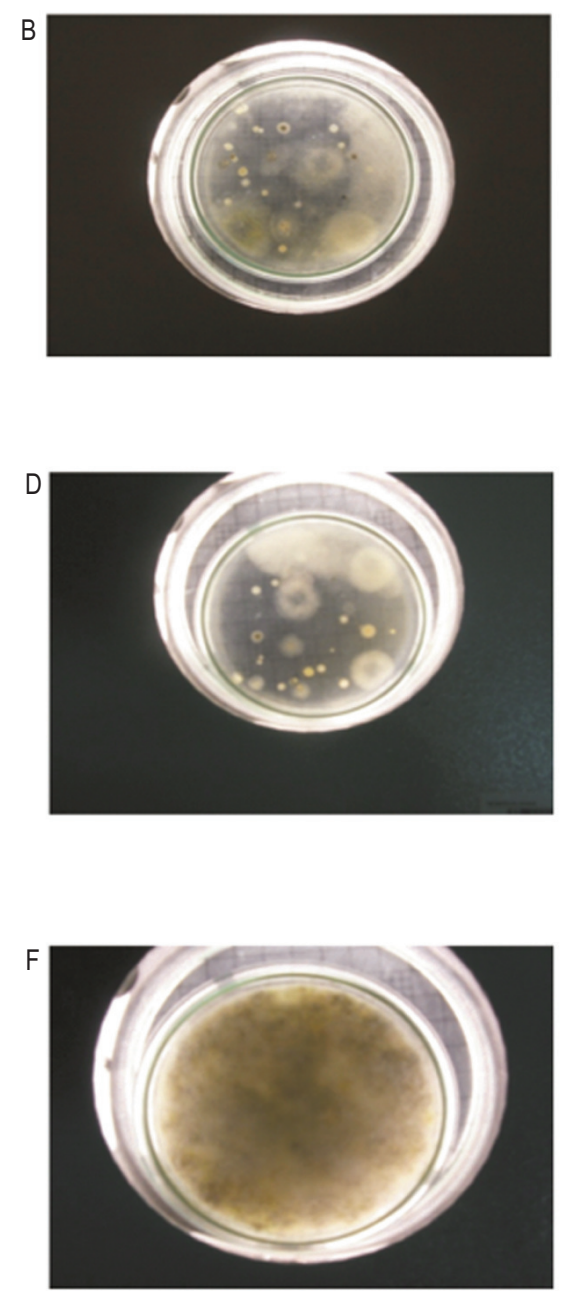

Fig. 2 : The microbial cultures of microfungi identified at six monitored places: A- painted canvas located in the hall at the entry into the wooden church; Baltar apse; $C$-interior left wall; $D$-interior right wall; $E$ - exterior left wall and $F$ - exterior right wall. 


\section{Acknowledgments}

The authors would like to thank anonymous reviewers for their suggestions and comments, and also acknowledges the support of grant PN-III-P1-1.2-PCCDI-2017-0686.

\section{References}

Akgul, H., C. C. Ergul, D. Yilmazkaya, I. Akata, F. Selcuk and E. Huseyin: Diversity of microfungi on fagaceae in Uludag forests. Oxid. Commun., 38, 1529-1538 (2015).

Anagnost, S.E., E.C. Setliff, S. Zhou and C.J.K. Wang : Frequency of basidiomycete fungi in the indoor air of urban homes. Proceedings of the Air and Waste. Management Symposium on Indoor Environmental Quality, Durham, North Carolina, (2006).

Azari, M.R., A. Ghadjari, M.R.M. Nejad and N.F. Nasiree: Air borne microbial contamination of dental units. Tanaffos, 7, 54-57 (2008).

Baias, S., M. Gozner, G.V. Herman and F.M. Măduța: Typology of wooden churches in the drainage basins of Mureș and Arieș, Alba County. University of Oradea Annals, Geography Series, 25, 221233 (2015).

Brochu, P., J.F. Ducré-Robitaille and J. Brodeur : Physiological daily inhalation rates for free-living individuals aged one month to 96 years, using data from doubly labeled water measurements : A proposal for air quality criteria, standard calculations and health risk assessment. Human Ecol. Risk Assess., 12, 675-701 (2006).

Brunekreef, B., D. Dockery and F.E. Speizer: Home dampness and respiratory morbidity in children. Am. Review of Respirat. Disea., 140, 1363-1367 (1989).

Bucșa, L. and C. Bucșa: Wood science for conservation of cultural heritage. Romanian wooden churches wall painting biodeterioration. Proceedi. of the Int. Conf. held in Braga (Portugal) (2008).

Bush, R.K., J.M. Portnoy, A. Saxon, A.I. Terr and R.A. Wood: The medical effects of mold exposure. J. Allergy Clin. Imunol., 117, 326-33 (2006).

Căpătînă, C., C. Racoceanu and G. Lazăr : Researches on air micro flora determination from public indoor spaces and hospital wards in an urban area. Environ. Eng. Manag. J., 6, 261-336 (2007).

Cernei, E.R., D.C. Maxim, R. Mavru and L. Indrei : Bacteriological analysis of air (aeromicroflora) from the level of dental offices in laşi County Romanian. J. Oral Rehab., 5 (2013).

Dales, R., H. Zwanenburg, R. Burnett and C. Franklin : Respiratory health effects of home dampness and molds among Canadian Children. Am. J. Epidem., 134, 196-203 (1991).

Gent, J.F., P. Ren, K. Belanger, E. Triche, M.B. Bracken, T.R. Holford and B.P. Lederer : Levels of house hold mold associated with respiratory symptoms in the first year of life in a cohort at risk for asthma. Environ. Hlth. Perspec., 110, 781-786 (2002).

Godea, I., I. Cristache-Panait, A. Chiriac and M. Malinas : Historic monuments from Eparhia of Oradea, Bihor, Salaj, Satu Mare Counties, Wooden churches. Press of Romanian Orthodox Diocese, Oradea, p. 341 (1978).

Gorny, R.L.: Filamentous microorganisms and their fragments in indoor air : Areview. Ann. Agric. Environ. Med. 11, 185-197 (2004).

Gorny, R.L., T. Reponen, K. Willeke, D. Schmechel, E. Robine, M. Boissier and S.A. Grinshpun : Fungal fragments as indoor air biocontaminants. Appl. Environ. Microbiol., 68, 3522-3531 (2002).

Howard-Reed, C., L.A. Wallace and S.J. Emmerich : Effect of ventilation systems and airfilters on decay rates of particles by indoor sources in an occupied town house. Atmosph. Environ., 37, 5295-5306 (2003).

Huixing, L., Z. Chenyu, S. Hao and F. Guohui: Detection and analysis of microbial contamination in museum's constant temperature and humidity air conditioning system. Proc. Eng., 205, 1179-1185 (2017).

Ilieș, A., J.A. Wendt, C.D. llieș, I. Josan and G.V. Herman: The Romanian rural architectural heritage from Maramureş Land - Personality, distinctiveness and protection. Studia Universitatis Babes-Bolyai, Geographia, 2, 187-197 (2011).

Ilieș, A.: Rural Churches,"pearls" of rural architecture in Crisana and Maramures. University of Oradea Annals, Geography Series, 23, 386-391 (2013).

Ilieș, A., Ş. Baias., I. Baias, L. Blaga, S. Buhaș, A. Chiriac, J. Ciocan, M. Dăncuș, A. Deac, P. Dragos, G. Dumitrescu, O. Gaceu, I. Godea, M. Gozner, V. Grama, G.V. Herman, N. Hodor, P. Hurley, C.D. Ilies, G. Ilieș, M. Ilieș, I. Josan, G. Leșe, F.M. Măduța, D. Mojolic, C. Morar, M. Olaru, M. Stașac, M. Stupariu, A. Sturza, B. Ștefănescu, C. Tătar, R. Vârnav, M. Vlaicu and J.A. Wendt: Geographical atlas of tourism heritage. University of Oradea Press, Oradea, 13-171 (2014).

Ilieș, A., J. Wendt, D. C. llieș, G. V. Herman, M. llieș and A.L. Deac: The patrimony of wooden churches, built between 1531 and 2015, in the Land of Maramureș, Romania. J. Maps, 12, 597-602 (2016).

Katja, S.: Fungi : Their role in deterioration of cultural heritage. Fung. Biol. Rev., 24, 47-55 (2010).

Miller, J.D.: Fungi as contaminants of indoor air. Atm. Environ., 26, 21632172(1992)

Mondal, N.K., R. Bhaumik, C.R. Das, P. Aditya, J.K. Datta, A. Banerjee and K. Das: Assessment of indoor pollutants generated from bio and synthetic fuels in selected villages of Burdwan, West Bengal. J. Environ. Biol., 34, 963-966 (2013).

Oneț, C.: Environmental Hygiene. University of Oradea Publishing House (2012).

Rached, I., F. Aviat, V. Michel, I. LE Bayon, P. Gay-Perret, M. Kutnik and M. Fédérighi : Methods for recovering microorganisms from solid surfaces used in the food industry : A review of literature. Int. J. Environ. Res. Pub. Hlth., 10,6169-6183 (2013).

Samuel, F.H. and M.M. Abayneh : Microbiological quality of indoor air in University libraries : Asian. Pac. J. Trop. Biomed., 4 (Suppl 1), S312-S317 (2014).

Spengler, J.D., J.M. Samet and J.F. Mccarthy : Indoor Air Quality Handbook. McGraw-Hill, New York (2001).

Stark, P.C., H.A. Burg, L.M. Ryan, D.K. Milton and D.R. Gold: Fungal levels in the home and lower respiratory tract illnesses in the first year of life. Am. J. Resp. Critical Care Med., 168, 232-237 (2003).

Terr, A.I.: Are indoor molds causing a new disease?. Allergy Clin. Immunol., 113, 221-227 (2014).

Timar, M. C., E. Beldean, M. Porojan and L. Gurau : Field testing and microscopy - important tools for a realistic long-term evaluation of wood improvement treatments. Environ. Eng. Manag. J., 8, 6331002 (2009).

Vlad, C.: Determining the species and number of pathogens present in the air inside public buildings and educational institutions in the Timisoara City (2009).

Yassin, M.F. and S. Almouqatea: Assessment of airborne bacteria and fungi in an indoor and outdoor environment. Int. J. Environ. Sci. Technol., 7, 535-544 (2010).

Yasir, M., P. Singh, M. K. Tripathi, I. A. Tayubi and R. Shrivastava: Antioxidant and antifungal activity of Glycosmis pentaphylla roots against dermatophytes and yeast-like fungi responsible for various skin ailments. Oxida. Communi., 38, 1622-1631 (2015).

Zehra, A., M.K. Dubey, M. Meena and R.S. Upadyay: Effect of different environmental conditions on growth and sporulation of some Trichoderma species. J. Environ. Biol., 38, 197-203 (2017). 